体力科学 (2000) 49, 103 110

中年女子レクリエーション泳者のシンクロナイズド・スイミング時の生理学的応答

山村千晶塚嶋洋子松井信夫北川薫

\title{
PHYSIOLOGICAL ANALYSIS OF SYNCHRONIZED SWIMMING IN RECREATIONAL FEMALE MIDDLE-AGED SWIMMERS
}

Chiaki Yamamura, Yoko Tsukashima, Nobuo Matsui and Kaoru Kitagawa

\begin{abstract}
This study was designed to analyze physiologically recreational synchronized swimming and speed swimming. Two types of recreational synchronized swimming (Long face-in time performance : LFIP and Short face-in time performance: SFIP) and maximum exertion in the 200-m free style swimming ( $200 \mathrm{mFR})$ were measured in six recreational middle-aged female swimmers. LFIP and SFIP were conducted in shallow water. The percentage of face-in time for LFIP was about $10 \%$ longer than that of SFIP. Heart rate (HR) during each exercise was measured continuously. Blood lactate concentration ( $\mathrm{La}$ ), the rate of perceived exertion (RPE) and systolic and diastolic blood pressure (SBP, DBP) were measured after each exercise. Average HR during the LFIP, SFIP and 200 $\mathrm{mFR}$ were $133 \pm 12,132 \pm 13$ and $153 \pm 12$ beats $\cdot \mathrm{min}^{-1}$ (mean $\pm \mathrm{SD}$ ), respectively. La was $2.4 \pm 0.7$ $\mathrm{mmol} \cdot 1^{-1}$ for LFIP, $2.2 \pm 0.6 \mathrm{mmol} \cdot 1^{-1}$ for SFIP and $5.7 \pm 2.4 \mathrm{mmol} \cdot 1^{-1}$ for $200 \mathrm{mFR}$, respectively. SBP was $181 \pm 32 \mathrm{mmHg}$ for LFIP, $166 \pm 22 \mathrm{mmHg}$ for SFIP and $185 \pm 30 \mathrm{mmHg}$ for $200 \mathrm{mFR}$, respectively. No significant differences were observed in blood pressure among the three exercises. SBP of $200 \mathrm{mmHg}$ or higher after LFIP and $200 \mathrm{mFR}$ was observed in some subjects. HR, La and RPE for LFIP and SFIP showed no significant differences, but were significantly lower than those of 200 $\mathrm{mFR}$. These results show that the exercise intensity of LFIP was moderate and was similar to that of SFIP. LFIP, however, caused a marked rise in SBP. Thus, SFIP may be more recommended for health promotion to recreational middle-aged swimmers than LFIP.
\end{abstract}

(Jpn. J. Phys. Fitness Sports Med. 2000, $49: 103 \sim 110$ )

key words : synchronized swimming, middle-aged, speed swimming, blood pressure, heart rate

\section{I. 粕}

水泳は, 浮力によって関節にかかる負担が軽減 されることや水の持つ粘性により転倒しにくいな ど，陸上運動にはみられない特性から中高年齢者 の間で広く行われている1). 近年は水泳だけに限 らず，立位で一定の動作を繰り返す水中走行や水 中歩行, 音楽に合わせてリズミカルに様々な動作 を行うシンクロナイズド・スイミングや水中エア ロビクスなど，水中で実施される運動の種類は多 岐にわたっている.なかでも音楽を用いる運動は, 音楽のテンポを変化させることにより運動強度を 調節する事ができるので, 対象者に合わせた内容
の運動を実施しやすいなどの利点がある ${ }^{2,3)}$ ，と の報告が陸上運動時になされている.

生体は，水に入ることによって陸上とは異なる 生理学的応答を示すが4 6)，このような応答は 全ての年齡層において同様に見られるのではな く，加齢により変化する ${ }^{7,8)}$. そのため, 中高年 齢者に運動を処方する際，若年齢者を対象とした 結果をそのままあてはめることは不適当であると 考えられる．特に，音楽を用いる水中運動に関す るこれまでの報告は，競技選手 ${ }^{9 \sim 13)}$ や若年齢者 14,15) を対象としており，中高年齢者を対象とし た先行研究は著者らの知る限りない。また，息こ らえを伴う水中運動では, 心拍数(以下, HR)の
中京大学体育学部運動生理学研究室 干470-0348 愛知県豊田市貝津町床立101
Laboratory for Exercise Physiology and Biomechanics, School of Physical Education, Chukyo University. 101 Tokodachi kaizu-cho, Toyota, 470-0348, Japan 
低下や血圧の上昇が顕著にみれらることが報告さ れている16〜18).

そこで，本研究では中年龄者によりレクリエー ション的に行われている水中運動の特性を明らか にするために， 2 種類のシンクロナイズド・スイ ミングについて, 以下の点を検討した.ハイブリッ ドフィギュアなどを含み, 顔を水につけることに より呼吸ができない状態の時間(以下, Face-in time) ${ }^{19)}$ が後述の演技よりは長い演技 (Long facein time performance : LFIP) とリズム水泳の泳法 が中心となり, LFIP よりは Face-in time が短い 演技 (Short face-in time performance: SFIP) とを 比較する.さらに, 本研究でのシンクロナイズド・ スイミングと運動時間が同程度となる， $200 \mathrm{~m}$ 自 由形全力泳 (以下, $200 \mathrm{mFR}$ )についても同様の測 定を行った.

\section{II. 方法}

\section{A. 対 象}

被検者は健康な中年女子シンクロナイズド・ス イミング愛好者 6 名であり, 年龄の平均值と標準 偏差は44.1土8.0(31.5 51.8)歳, 経験年数は6.8 $\pm 3.1(4$ 12) 年であった. トレーニングの頻度 と時間は, 1 週間に $1 \sim 2$ 回, 1 回あたり約 2 時 間であった。なお，1名を除き被検者はシンクロ ナイズド・スイミング以外にも競泳を 1 週間に 1 〜 2 回, 1 回あたり約 1 時間行っていた. また, 本研究は中京大学大学院体育学研究科における 「人を対象とする研究に関する倫理指針」にのっ とり，全ての実験の前には，被検者に対して実験 内容について十分な説明を行い, その内容を理解 した上で，承諾書への署名を得た。

\section{B . 测定項目}

1. 身体的および機能的特徽

形態的測定として身長, 体重, 周径囲 (腹部最 小囲, 警囲, 上腕囲, 大腿囲)および身体組成を 測定した，身体組成の測定は，Bモード超音波皮 下脂肪厚計(SM 206：諴鋼社製)を用いた。

機能的測定としての筋力 (握力), 筋持久力 (上 体おこし), 瞬発力 (立幅跳び), 平衡性 (閉眼片足
立ち), 禿軟性(伏臥上体そらし)および呼吸機能 関連 (最高酸素摄取量 (以下, $\mathrm{VO}_{2}$ peak), 運動後 息こらえ, 肺活量, 1 秒量)の測定については, 日本人の体力標準值第 4 版 ${ }^{20)} に$ 揭載されている 方法に従って行った. なお， $\mathrm{VO}_{2}$ peak の測定に ついては,これと異なる方法を用いて行ったため, 以下に測定方法を記した。

$\mathrm{VO}_{2}$ peak は自転車エルゴメーター(エアロバイ ク800：コンビ社製)を用いて, 負荷を $0 \mathrm{~W}$ から 1 分毎に $15 \mathrm{~W}$ ずつ增加させて被検者を疲労困樯 に至らせた。酸素摄取量 (以下, $\mathrm{VO}_{2}$ )の測定は, オキシコンシグマ(フクダ電子社製)を用いて30秒 毎に連続的に行った. HR はテレメーター送信器 (ST-17：フクダ電子社製)およびダイナスコープ (DS-502：フクタ電子社製)を用いて胸部双極誘 導法によって測定した。また，同時に血圧 (STBP-680：日本コーリン社製)の測定および主 钼的運動強度 (以下, RPE)の記録を小野寺と宮 下 ${ }^{21)}$ のスケールを用いて行った。 なお，運動の 中止基準は $\mathrm{VO}_{2}$ の leveling off がみられること, ペタルを規定の回転数で漕ぎ続けられないこと, 呼吸交換比が 1.0 以上であることのうち 2 項目以 上が確認される時とした，従って, 最大酸素摄取 量が得られたと判定できる例もあったが, 本研究 では $\mathrm{VO}_{2}$ の最大值を $\mathrm{VO}_{2}$ peak とした.

\section{2. 水中での運動時における生理学的応答} 水中での運動時の測定は, Face-in time の異な る 2 種類の演技(LFIP および SFIP) と $200 \mathrm{mFR}$ を行った際に実施した。なお，これらの測定は 1 種目ずっ日を変えて行った。

HR の測定はハートレートモニタートランス ミッター(Polar Vantage XL : Polar 社製)を用い て，運動中 5 秒間ごとに連続して記録した。血中 乳酸鈛度については, 各運動終了の直後, 3 分目 および 5 分目に指先から採血を行い, 直ちにラク テートアナライザー(1500 sports : YSI 社製)を用 いて分析し，それらの最大值を測定結果として用 いた。 また，血圧の測定および RPE の記録は運 動終了の直後に行ったが, Rive-Rocci 型の水銀 血圧計のマンシェットを巻くための時間等が必要 
であったため, 実際の測定は運動終了の約 1 分後 であった.

\section{C. 測定種目}

現在, 中高年齢者がシンクロナイズド・スイミ ングを行う際は, 水深の浅いプールにおいて,プー ルの底に手足をついてもよい形式と，水深の深い プールにおいてプールの底に手足を一切つかない 形式にて行われている．本研究ではいずれの演技 も水深が約 $1.2 \mathrm{~m}$ のプールにて前者の形式で 行った. 各演技の Face-in time については, Homma の報告 ${ }^{19)}$ に従い録画ビデオから算出し た.
また， $200 \mathrm{mFR}$ は運動開始を水中からとし， 被検者にはあらかじめ $200 \mathrm{~m}$ を全力で泳ぐよう に指示した。

\section{D. 統計処理}

データの統計処理は一元配置の分散分析法を用 いて行い, 有意差が認められた項目については, Tukey の post hoc test を適用した。なお，統計 上の有意水準は全て危険率が 5 \% 未満とした。

\section{III. 結果}

被検者の身体的および機能的特徽については Table 1 に示した.

Table 1. Anthropometric and physical fitness data of the subjects.

$(\mathrm{n}=6)$

\begin{tabular}{|c|c|c|c|}
\hline Variable & Mean $\pm S D$ & iVariable & Mean \pm SD \\
\hline Anthropometric data & & 'Physical fitness data & \\
\hline Height (cm) & $161.5 \pm 4.8$ & Grip strength (kgw) & $26.6 \pm 2.9$ \\
\hline Weight (kg) & $50.6 \pm 4.3$ & Sit-ups for 30 s (time) & $19.0 \pm 5.5$ \\
\hline Circumference (cm) & & Standing long jump (cm) & $166.6 \pm 19.0$ \\
\hline Minimum Abdomen & $65.3 \pm 3.1$ & Closed-eyes foot-balance (sec) & $29.2 \pm 22.8$ \\
\hline Hip & $89.0 \pm 2.4$ & Prone trunk extension $(\mathrm{cm})$ & $50.8 \pm 5.9$ \\
\hline Upper Arm & $25.9 \pm 1.5$ & VंOzpeak/ wt (ml $\left.\cdot \mathbf{k g}^{\prime} \cdot \min ^{\prime}\right)$ & $37.6 \pm 4.9$ \\
\hline Thigh & $50.2 \pm 2.7$ & Breath holding time after exercise (sec) & $15.7 \pm 2.9$ \\
\hline Body composition & & Vital capacity (L) & $3.70 \pm 0.44$ \\
\hline$\%$ Fat $(\%)$ & $21.0 \pm 2.3$ & Timed vital capacity (L) & $2.99 \pm 0.38$ \\
\hline Fat (kg) & $10.6 \pm 1.0$ & Resting heart rate in water (beats $\cdot \mathrm{min}^{-1}$ ) & $73.3 \pm 8.2$ \\
\hline \multirow[t]{2}{*}{ LBW (kg) } & $40.0 \pm 4.2$ & Resting SBP $(\mathrm{mmHg})$ & $122 \pm 16$ \\
\hline & & Resting DBP (mmHg) & $73 \pm 17$ \\
\hline
\end{tabular}

\%Fat: percentage of body fat, Fat : body fat, LBW : lean body weight, $\mathrm{VO}_{2 \text { peak }}$ : peak oxygen uptaka, /wt: relative value to $1 \mathrm{~kg}$ of body weight, SBP : systolic blood pressure, DBP : diastolic blood pressure.

Table 2. Heart rate during synchronized swimming and $200-\mathrm{m}$ free style swimming.

$(\mathrm{n}=6)$

\begin{tabular}{c|c}
\hline Event & Mean \pm SD (beats $\cdot$ min $\left.^{-1}\right)$ \\
\hline LFIP & $132.9 \pm 11.9$ \\
SFIP & $132.0 \pm 12.5$ \\
$200 m F R$ & $153.4 \pm 11.5^{\star}$ \\
\hline
\end{tabular}

LFIP : Long face-in time performance, SFIP : Short face-in time performance, $200 \mathrm{mFR}: 200$-m free style swimming.

※ : Significantly higher than LFIP and SFIP.
Table 2 には各水中での運動中を連続記録した HR の平均值と標準偏差を示した. Fig. 1 には運 動中に連続記録した HR を被検者Fの結果を例に して示した．水中立位安静時の HR の平均値と標 準偏差は, $73.3 \pm 8.2$ beats $\cdot \mathrm{min}^{-1}$ であった。 運動中の HR は LFIP と SFIP との差において有 意ではなかった。しかし， $200 \mathrm{mFR}$ に比較する といずれの HR も有意に低かった。 また，安静時 の血中乳酸濃度, 収縮期血圧 (以下, SBP) および 拡張期血圧 (以下, DBP)の平均值と標準偏差は, 


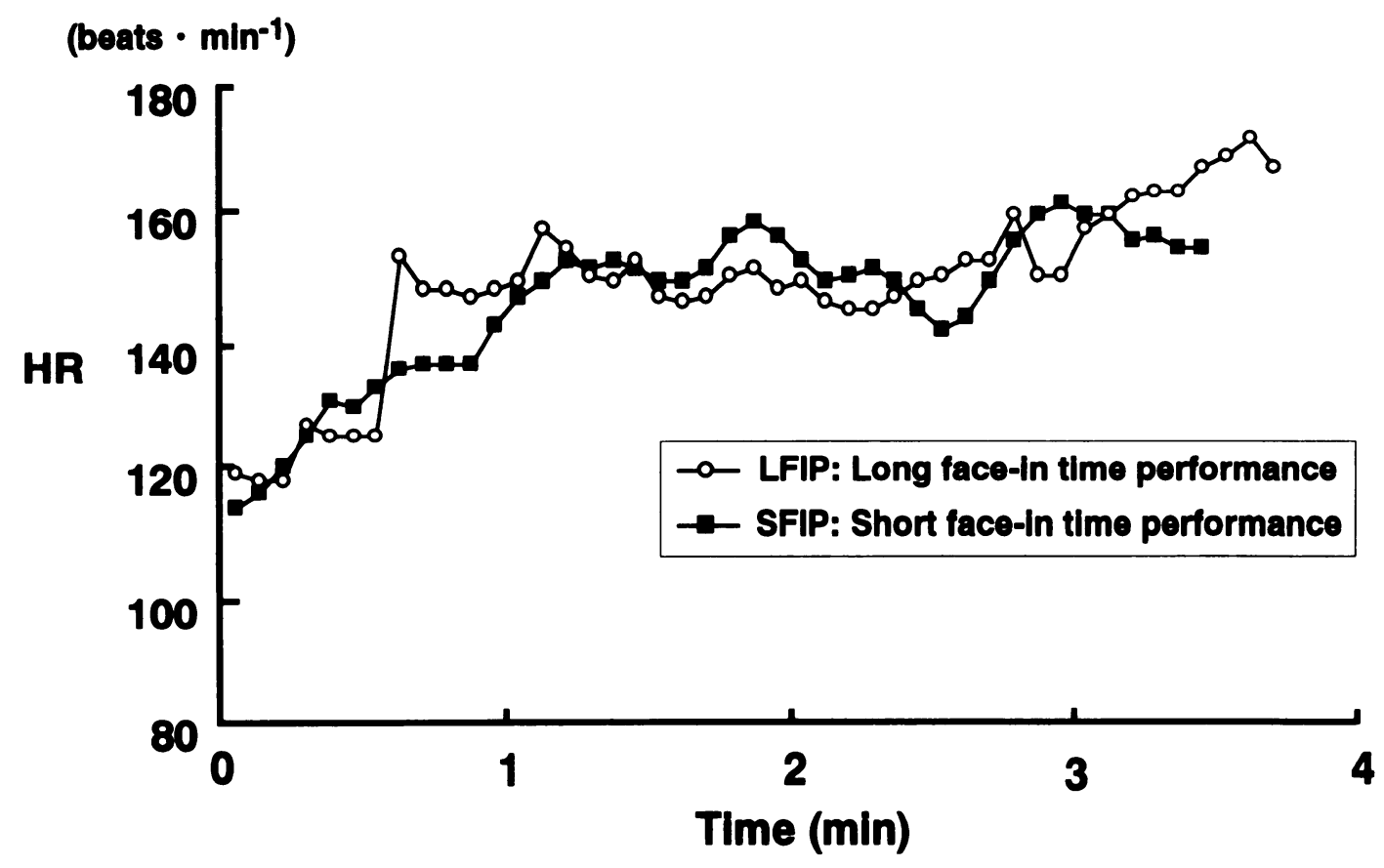

Fig. 1. Change of heart rate during synchronized swimming (Subject F).

それぞれ $1.2 \pm 0.3 \mathrm{mmol} \cdot 1^{-1}, 122 \pm 16 \mathrm{mmHg}$ お よび $73 \pm 17 \mathrm{mmHg}$ であった. Fig. 2 に示したの は, 演技終了後の血中乳酸渾度, RPE, SBP およ び DBP である．血中乳酸濃度と RPE の平均値 と標準偏差は, LFIP が $2.4 \pm 0.7 \mathrm{mmol} \cdot 1^{-1}$ と $13.2 \pm 3.0$, SFIP が $2.2 \pm 0.6 \mathrm{mmol} \cdot 1^{-1}$ と 10.5 $\pm 1.2,200 \mathrm{mFR}$ が $5.7 \pm 2.4 \mathrm{mmol} \cdot 1^{-1}$ と 16.5 \pm 2.3 であった. LFIP とSFIP の血中乳酸濐度 とRPEには有意な差がみられなかったが，200 $\mathrm{mFR}$ に比較するといずれも有意に低かった. SBP と DBP は, LFIP が $181 \pm 32 \mathrm{mmHg}$ と $88 \pm$ $21 \mathrm{mmHg}$, SFIP が $166 \pm 22 \mathrm{mmHg}$ と $83 \pm 13$ $\mathrm{mmHg}, \quad 200 \mathrm{mFR}$ が $185 \pm 30 \mathrm{mmHg}$ と $71 \pm 15$ $\mathrm{mmHg}$ であった. SBP と DBP には有意な差がみ

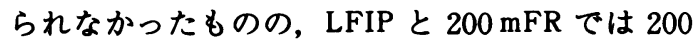
$\mathrm{mmHg}$ 以上の SBP を示す被検者が各々 2 名みら れた。 なお，彼らの LFIP での HR と血中乳酸婊 度は平均值と比較してやや高かった。 また，200 $\mathrm{mFR}$ の HR において一方の被検者は平均値より やや高く，他方はやや低かったが，血中乳酸濐度 はいずれもやや低かった。
演技を分析した結果，LFIP およびSFIP の演 技時間はそれぞれ 3 分 45 秒と 3 分 30 秒であり，全 演技時間に占める Face-in time の割合は, LFIP

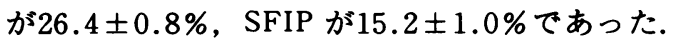
演技構成上, 各被検者が異なるタイミングで別々 の動きをするために，同一の演技であっても被検 者間での Face-in time は異なる. そのため，各 演技の Face-in time には標泍偏差にみられるよ うなばらつきがあった。このようなLFIP と SFIP の Face-in time の差は, LFIP が顔あげの 平泳ぎや背泳ぎなどのリズム水泳の泳法に加え， ハイブリッドフィギュアなどを含む構成であった のに対し，SFIP がリズム水泳の泳法を中心とし た構成であったことによる，一方，200 mFRの 平均夕イムは 3 分 46 秒 $23 \pm 25$ 秒 68 であり, LFIP やSFIP とほほ同程度の運動時間であった。

\section{N. 考察}

本研究の被検者の身体的および機能的特徽をこ れまでに報告されている，特別にスポーツ活動 を行っていない同年代の女子の結果と比較する 


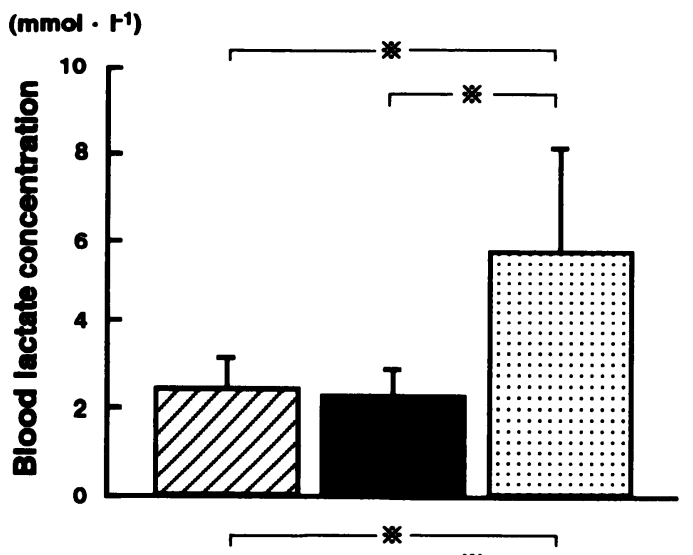

足立ち以外の全ての測定項目において高かった が, なかでも上体おこし, $\mathrm{VO}_{2}$ peak, 肺活量, 1 秒量および伏臥上体そらしはかなり優れているこ とがわかった。

シンクロナイズド・スイミングでは演技中の $\mathrm{VO}_{2}$ の測定が不可能なことから, 本研究では $\mathrm{HR}$, $\mathrm{RPE}$ および血中乳酸湿度を指標にして, 演技中 の運動強度と代謝状況を検討した．LFIP と SFIP の HR は Table 2 に示したように約 130 beats • $\mathrm{min}^{-1}$ であったことから，これらの演技の全体 としての運動強度はいずれも中等度であり, HR を指標としてみた場合，中年齢者が実施する健康 の維持・増進のために行う運動としては適当な強 度であると考えられた ${ }^{22)}$ 。ただし，同一の $\mathrm{VO}_{2}$ を摂取する際，水泳中の HR は陸上時のそれと比 較して低いことが報告されている 23 26). 。のた め,これらの演技は陸上での約 140 beats • $\min ^{-1}$ の運動と同程度となり, 酸素摄取水準は 約 $70 \% \mathrm{VO}_{2} \max$ に相当する ${ }^{27)}$. いずれにしても， HR を指標としてみた場合， LFIP や SFIP は中年 齢者にとって適当な強度の運動である ${ }^{22)}$.

LFIP と SFIP 終了後の血中乳酸漕度には, 両 者の間に有意な差はみられなかった。また，運動 時の血中乳酸濃度は, 安静時よりそれぞれ $1.2 \pm$ $0.6 \mathrm{~m} \mathrm{~mol} \cdot 1^{-1}$ と $1.0 \pm 0.3 \mathrm{mmol} \cdot 1^{-1}$ の增加し か示さなかった。 そのため, これらの演技中は, 無酸素性代謝よりも有酸素性代謝の関与の割合が 高かったものと考えられた。

本研究では循環系機能の指標として, 運動終了 後の血圧の測定を行った。演技時における $\mathrm{HR}$, 血中乳酸濃度および RPE は，200 mFR に比較す るといずれも有意に低かったにもかかわらず, SBP と DBP には 3 種目間で有意な差がみられな かった(Table 2, Fig. 2)。特に, LFIP の SBPは $200 \mathrm{mFR}$ に近い值にまで上昇しており，DBPに

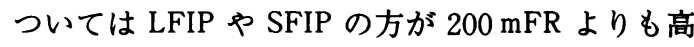
かった。これまで，息をこらえた直立位における 頸までの浸水および全身浸水，あるいは安静およ び運動時の顔面浸水中において血圧の上昇がみら れることが報告されている ${ }^{16,28 \sim 31)}$.このよう な血圧の上昇は, 全身の末梢抵抗の増加によるも た. 一方，機能的側面については，握力と閉眼片 
のであり，息こらえ時間の延長に伴いその上昇度 が高くなることが報告されている31)。これは， 息こらえによって血液中の二酸化炭素濃度が増加 するため, 脳や心荿への酸素供給が維持されるよ う，末梢血管の収縮によってこれらの器官への血 液配分が増加しているものと考えられている ${ }^{32)}$.

また，全身運動では血管拡張が全身に起るが, 局所運動ではその運動に動員される筋の血管は拡 張し，動員されない筋の血管は収縮する，そのた め, 同一酸素摄取量時では, 全身運動より局所運 動において血圧が高くなることが報告されてい $3^{33,34)}$. 本研究では, 水深の浅いプールにおい て演技を実施したため, 被検者はサポートスカー リングやエッグビーターなどを用いず，プールの 底に手や足をついた状態でハイブリッドフィギュ アやアームムーブメントを行っていた，さらに， バレーレッグなどのスカーリングのみで身体を支 える動作も含まれていた。つまり，全身運動であ る $200 \mathrm{mFR}$ と比較すると, LFIP は局所運動であ るため, 運動中に動員される筋量は少なかった可 能性がある，そのため，LFIP では $200 \mathrm{mFR}$ と同 水準の血圧の上昇がみられたものと考えられた.

本研究では LFIP 終了後の SBP が $200 \mathrm{mmHg}$ を超えている者が 2 名みられた。血圧は運動終了 後，急激に低下することから，演技中はさらに高 い值まで上昇していた可能性が高い.このような 血圧の上昇は, 心筋梗塞や脳の小動脈破裂による くも膜下出血などの心婼血管系の事故の誘因にな りうると考えられる，そのため，演技の構成にあ たっては対象者の血圧応答にも留意する必要があ ると考えられた。

\section{V.まと め}

本研究では中年女子6名を対象に, LFIP, SFIP および $200 \mathrm{mFR}$ 時の生理学的応答について検討 した. その結果, LFIP は HR の平均値からみる と全体としての運動強度は中等度であり, SFIP と同程度であったことが明らかとなった。 また， HR や運動後の血中乳酸濃度測定より, LFIP SFIP は中年齢者が健康の維持・増進のために行 う有酸素運動として適当と考えられる.しかし,
LFIP はSFIP に比較し血圧の上昇が高い傾向に あり, $200 \mathrm{mFR} に$ 近い值にまで上昇していた。 また, LFIP では $200 \mathrm{mmHg}$ 以上の SBP を示す者 がみられた. 従って, 中年齢者がレクリエーショ ン的に本研究でのようなシンクロナイズド・スイ ミングを行う際は, LFIP と同程度の運動強度で ありながら Face-in time が短く, LFIPよりも血 圧の上昇が低い傾向にある SFIP の方が奨励でき る運動内容であると考えられる，また，大きな血 圧上昇を引き起こさないように演技構成には注意 を払う必要があると考えられる。

\section{謝 辞}

本研究を遂行するにあたって, 名古屋シンクロ同好 会の坂口康子先生および会員の皆様ならびに中京大学 運動生理学研究室の本田亜紀子助手およびスタッフの 多大なる御協力を得たことをここに記し感謝申し上げ ます。

（受理日 平成11年 9 月 18 日）

\section{引用文 献}

1）井上大輔, 武藤芳照. 中高年の水泳の効用と障害, 臨床スポーツ医学, (1992)，9，410-415.

2) 沢井史穂. エアロビックダンスの生理学的・カ学 的運動強度の評価, Jpn. J. Sports Sci., (1994), 13 , 537-544.

3）植屋節子, 竹島伸生, 植屋悦男, 小林章雄, 加藤 孝之. 高龄者の運動処方としてのエアロビクスタ ンスーテンポと運動強度についてー, 臨床スポー ツ医学, (1993), 10, 961-965.

4) Begin, R., Epstein, M., Sackner, M. A., Levinson, R., Dougherty, R. and Duncan, D. Effects of water immersion to the neck on pulmonary circulation and tissue volume in man. J. Appl. Physiol., (1976), 40. 293-299.

5) Wei $\beta$, M., Hack, F., Stehle, R., Pollert, R. and Weicker, H. Effects of temperature and water immersion on plasma catecholamines and circulation. Int. J. Sports Med., (1988), 9, S113-S117.

6) Choukroun, M.-L. and Varene, P. Adjustments in oxygen transport during head-out immersion in water at different temperatures. J. Appl. Physiol., (1990), 68, 1475-1480.

7）杉山由樹, 美和千荇, 鈴木初恵,薛 叶祥, 松川俊義, 岩瀬 敏, 間野忠明. 高龄者における中立温澒下 水漫負荷時の循環動態, 環研年報, (1993)，14, 68-71.

8）美和千壀, 岩瀬 敏, 間野忠明, 斉藤 満, 杉山 由樹, 鈴木初恵. 水浸時におけるとトの筋交感神 経活動の抑制反応に対する加龄の影慗, 自律神経, 
(1993), 30, 16-23.

9) Figura, F., Cama, G. and Guidetti, L. Heart rate, alveolar gases and blood lactate during synchro. nized swimming. J. Sports Sci., (1993), 11, 103-107.

10) Gemma, K. E. and Wells, C. L. Heart rates of elite synchronized swimmers. Physician and sportsmedicine, (1987), 15, 99-107.

11）山村千晶, 宮城 修, 図司早江子, 石河利寛, 松 井信夫, 北川䔡. シンクロナイズド・スイミン グのフリールーティン時の運動強度, 体力科学, (1998), 47, 199-207.

12) 山村千晶, 北川 荽. シンクロナイズド・スイミ ングの体力学的研究, バイオメカニクス研究, (1998), 2, 2-9.

13) Yamamura, C., Zushi, S., Takata, K., Ishiko, T., Matsui, $\mathrm{N}$. and Kitagawa, K. Physiological characteristics of well-trained synchronized swimmers in relation to performance scores. Int. J. Sports Med. (1999), 20 , 246-251.

14) Eckerson, J. and Anderson, T. Physiological response to water aerobics. J. Sports Med. Phys. Fitness. (1992), 32, 255-261.

15）安田徒生, 山下亜希子, 道用 亘, 山本博男. $ア$ クアビクスの運動強度一楽しくシェイプアップを 目指して一, 体育の科学, (1996), 46, 546-551.

16) Andersson, J. and Schagatay, E. Effects of lung volume and involuntary breathing movements on the human diving response. Eur. J. Appl. Physiol., (1998), 77, 19-24.

17) Bergman, S. A. Jr., Campbell, J. K. and Wildenthal, $\mathrm{K}$. "Diving reflex" in man: its relation to isometric and dynamic exercise. J. Appl. Physiol., (1972), 33. 27-31.

18) Kawakami, Y., Natelson, B. H. and DuBois, A. B. Cardiovascular effects of face immersion and factors affecting diving reflex in man. J. Appl. Physiol., (1967), 23, 964-970.

19) Homma, M. The components and the time of 'face in' of the routines in synchronized swimming. In., Hebbelinck, M. and Shephard, R. J., Medicine and Sport Science, Vol. 39, Karger, Basel, (1994), 149-154.

20) 東京都立大学体育学研究室. 日本人の体力標準值 第 4 版，第 4 版，不昧堂，東京，(1989），9-369.

21）小野寺孝一，宮下充正. 全身持久性運動における 主観的強度と客観的強度の対応性一Rating of per ceived exertionの観点から一, 体育学研究, (1976), 21, 191-203.
22) American College of Sports Medicine. The recommended quantity and quality of exercise for developing and maintaining cardiorespiratory and muscular fitness, and flexibility in healthy adults. Med. Sci. Sports Exerc., (1998), 30, 975-991.

23) Magel, J. R. and Faulkner, J. A. Maximum oxygen uptakes of college swimmers. J. Appl. Physiol., (1967), 22, 929-933.

24) McArdle, W. D., Glaser, R. M. and Magel, J. R. Metabolic and cardiorespiratory response during free swimming and treadmill walking. J. Appl. Physiol., (1971), 30, 733-738.

25) Holmér, I. and Àstrand, P.-O. Swimming training and maximal oxygen uptake. J. Appl. Physiol., (1972), 33, 510-513.

26）涌井忠昭, 高橋繁浩, 北川 暴, 石河利寛. 水泳 および水中歩行における運動強度の指標としての 心拍数, 運動スピード, 主観的運動強度の有効性, 東海保健体育科学, (1987)，9，1-9.

27）山地啓司. 運動処方のための心拍数の科学, 初版, 大修館書店, 東京, (1981)，41-43.

28) Harding, P. E., Roman, D. and Whelan, R.F. Diving bradycardia in man. J. Physiol., (1965), 181, 401409.

29) Hong, S. K., Moore, T. O., Seto, G., Park, H. K., Hiatt, W. R. and Bernauer, E. M. Lung volumes and apneic bradycardia in divers. J. Appl. Physiol., (1970), 29. 172-176.

30) Bjertnaes, L., Hauge, A., Kjekshus, J. and S $\phi y l a n d$, E. Cardiovascular responses to face immersion and apnea during steady state muscle exercise. A heart catheterization study on humans. Acta. Physiol. Scand., (1984), 120, 605-612.

31) Pan, A.-W., He, J., Kinouchi, Y., Yamaguchi, H. and Miyamoto, H. Blood flow in the carotid artery during breath-holding in relation to diving bradycardia. Eur. J. Appl. Physiol., (1997), 75, 388-395.

32) Lin, Y.-C. Applied physiology of diving. Sports Med., (1988), 5, 41-56.

33) Astrand, P.-O., Ekblom, B., Messin, R., Saltin, B. and Stenberg. J. Intra-arterial blood pressure dur. ing exercise with different muscle groups. J. Appl. Physiol., (1965), 20, 253-256.

34) Blomquist, C. G., Lewis, S. F., Taylor, W. F. and Graham, R. M. Similarity of the hemodynamic responses to static and dynamic exercise of small muscle groups. Circ. Res., (1981), 48, I87-I92. 